\title{
Phosphate Transport by Intestinal Endoplasmic Reticulum during Maturation
}

\author{
FAYEZ K. GHISHAN AND NOUSHIN ARAB \\ Vanderbilt University, Department of Pediatrics, Division of Gastroenterology/Nutrition, Vanderbilt Medical \\ School, Nashville, Tennessee 37232
}

\begin{abstract}
The transport of phosphate into jejunal endoplasmic reticulum vesicles isolated from suckling and adolescent rats was investigated using a rapid filtration technique. Intestinal endoplasmic reticulum from both ages were enriched with NADPH cytochrome-C-reductase whereas other markers for brush border, basolateral, mitochondrial, and Golgi apparatus were impoverished. Phosphate uptake represented an energy-dependent process as evident by more than $80 \%$ decrease in uptake values at $0^{\circ}$ $\mathrm{C}$ compared to $25^{\circ} \mathrm{C}$. Phosphate uptake was ATP dependent in both age groups, however, mean uptake values were significantly greater in suckling rats compared to adolescent rats. pH optimum for uptake was 7.2. p-Chloromercuribenzoate at $100 \mu \mathrm{M}$ concentration inhibited phosphate uptake by more than $90 \%$. Initial rate of phosphate uptake was linear up to $45 \mathrm{~s}$. Kinetics of phosphate uptake at 30 s showed $a K_{m}$ of $0.7 \pm 0.1$ and $0.15 \pm 0.1$ suckling and adolescent rats, respectively. $V_{\max }$ was $1.5 \pm 0.5$ and 0.14 $\pm 0.01 \mathrm{nmol} / \mathrm{mg}$ protein $/ 30 \mathrm{~s}$ for both suckling and adolescent rats, respectively. Herein we provide evidence for the first time for the presence of a phosphate carrier in intestinal endoplasmic reticulum of rats. Endoplasmic reticulum of phosphate uptake was significantly greater in suckling rats compared to adolescent rats. This increase in uptake is due to a greater number and activity of phosphate carriers in suckling rats. (Pediatr Res 23: 612-615, 1988)
\end{abstract}

The transport of phosphate across the small intestine of suckling and adult animals occurs by an active process (1-5). Jejunal phosphate transport take place against an electrochemical gradient and is inhibited by arsenate (1-8). The uptake of phosphate at the brush border membrane consists of two components: a saturable, electroneutral sodium dependent component and an unsaturable, sodium-independent component $(1,2)$. The energy driving the sodium-dependent entry of phosphate into the cell is provided by an extracellular to intracellular $\mathrm{Na}^{+}$gradient maintained by the $\mathrm{Na}^{+}-\mathrm{K}^{+}$-ATPase at the basolateral membrane (5). Both sodium-dependent and -independent brush border phosphate uptake are higher in suckling rats compared to adult rats (6). Phosphate exit at the basolateral membrane of the enterocyte occurs by a carrier-mediated process that is sodium dependent, electroneutral with stoichiometry of $2 \mathrm{Na:1}$ phosphate at $\mathrm{pH} 7.4$ (7). The transcellular movement of phosphate is unknown. Recently, we described an important role for the endoplasmic reticulum in transcellular calcium transport (8). This process is ATP dependent and exhibits characteristic devel-

Received November 9, 1987; accepted February 8, 1988.

Correspondence Fayez K. Ghishan, M.D., Vanderbilt University Medical Center, Department of Pediatrics, Division of Gastroenterology, D-4130 MCN, Nashville, TN 37232.

Supported by National Institutes of Health Grant RO1 AM33209-04. opmental patterns (8). Our study was designed to investigate the role of intestinal endoplasmic reticulum in phosphate transport during maturation in the rat. We used a millipore filtration system to study phosphate uptake by intestinal microsomes.

\section{EXPERIMENTAL PROCEDURES}

Isolation of intestinal endoplasmic reticulum vesicles. The jejunum of two adolescent rats ( $42 \pm 2$ days) of 12 suckling rats (14 \pm 1 day) were used to prepare the endoplasmic reticulum vesicles. Suckling rats were allowed to suckle freely from their mother. Weanling and adolescent rats were fed a regular diet containing $1.2 \%$ calcium, $0.8 \%$ phosphate, and $1700 \mathrm{U} / 100 \mathrm{~g}$ of ergocalciferol (Teklad diets, Madison WI). Rats were killed by cervical dislocation and enterocytes were prepared from jejunal segments. The jejunal region extended from the ligament of Treitz to 20,30 , and $50 \mathrm{~cm}$ aborally in suckling, weanling, and adolescent rats, respectively. The intestinal segments were removed, flushed with ice cold lactated Ringer's solution, and then filled with warmed buffer solution $\left(37^{\circ} \mathrm{C}\right)$ containing $1.5 \mathrm{mM}$ $\mathrm{KCl}, 96 \mathrm{mM} \mathrm{NaCl}, 8 \mathrm{mM} \mathrm{KH} \mathrm{PO}_{4}, 5.6 \mathrm{mM} \mathrm{Na}_{2} \mathrm{HPO}_{4}, 27 \mathrm{mM}$ $\mathrm{Na}_{3}$ citrate, and $2 \mathrm{mM}$ dithiothreitol (pH 7.2). The segments were then clamped and incubated for $15 \mathrm{~min}$ in a shaking water bath at $37^{\circ} \mathrm{C}$. The clamps were then removed and the contents were emptied. The segments were then filled with ice cold buffer containing $100 \mathrm{mM}$ mannitol, $100 \mathrm{mM} \mathrm{KCl}, 24 \mathrm{mM}$ Hepes/ Tris buffer $\mathrm{pH} 7.2$ and gently palpated by fingers for $5 \mathrm{~min}$ to release epithelial cells. The enterocytes were collected at $500 \times g$ for $10 \mathrm{~min}$. The enterocytes were then homogenized in a standard douche homogenizer in $75 \mathrm{ml}$ of sucrose buffer containing 250 $\mathrm{mM}$ sucrose, $10 \mathrm{mM}$ Hepes/Tris buffer pH 7.2, 1 mM EDTA, and $0.1 \mathrm{mM}$ phenylmethanesulfonyl fluoride. The homogenate was then centrifuged at $3,000 \times g$ for $10 \mathrm{~min}$ and the resulting supernatant was spun at $25,300 \times g$ for $20 \mathrm{~min}$. The pellet was then discarded and the supernatant was sedimented at 100,000 $\times g$ for $60 \mathrm{~min}$. The final pellet contained enriched endoplasmic reticulum vesicles. Using a similar method Rubinoff and Nellans (9) obtained enriched endoplasmic reticulum vesicles from adult rat enterocytes. The pellet was resuspended in the sucrose buffer and used in the studies as outlined below.

Materials. ${ }^{32} \mathrm{P}\left(\mathrm{KH}_{2}{ }^{32} \mathrm{PO}_{4} 1 \mathrm{Ci} / \mathrm{mmol}\right)$ was obtained from New England Nuclear, Boston, MA. Enzymes and substrates for leucine aminopeptidase were obtained from Sigma Chemical Co., St. Louis, MO. Cellulose nitrate filters were obtained from Sartorius Filters, Inc., CA. All other chemicals were obtained from Sigma.

Transport measurement. Uptake of phosphate was measured by a rapid filtration technique (13) as used previously in our laboratory (6-8). Briefly, vesicles obtained in the $100,000 \times g$ centrifugation were preincubated in a solution containing 120 $\mathrm{mM} \mathrm{KCl}, 5 \mathrm{mM} \mathrm{MgCl}_{2}$, and $10 \mathrm{mM}$ Hepes/Tris buffer, $\mathrm{pH}$ 7.2. All experiments were performed at $25^{\circ} \mathrm{C}$ except as indicated. Transport was initiated by the addition of $20 \mu \mathrm{l}$ vesicle protein 
to the desired incubation media containing labeled phosphate. The composition of the incubation media was similar to the preincubation media except for the addition or deletion of $5 \mathrm{mM}$ Tris ATP. The reaction was stopped by the addition of $5 \mathrm{ml}$ of ice cold incubation media containing $100 \mathrm{mM}$ mannitol, 100 $\mathrm{mM} \mathrm{NaCl}, 5 \mathrm{mM} \mathrm{KH} 2 \mathrm{PO}_{4}$, and $20 \mathrm{mM}$ Hepes/Tris buffer, $\mathrm{pH}$ 7.2. The vesicles were immediately collected on a cellulose nitrate filter $(0.45 \mu \mathrm{m}$-pore size, Sartorius Filters) and kept under suction while being washed with ice cold stop solution. The amount of radioactive substrate remaining on the filter was determined in a liquid scintillation counter (Beckman Instruments, Palo Alto, $\mathrm{CA}$ ) using Bray's solution (New England Nuclear) as a liquid

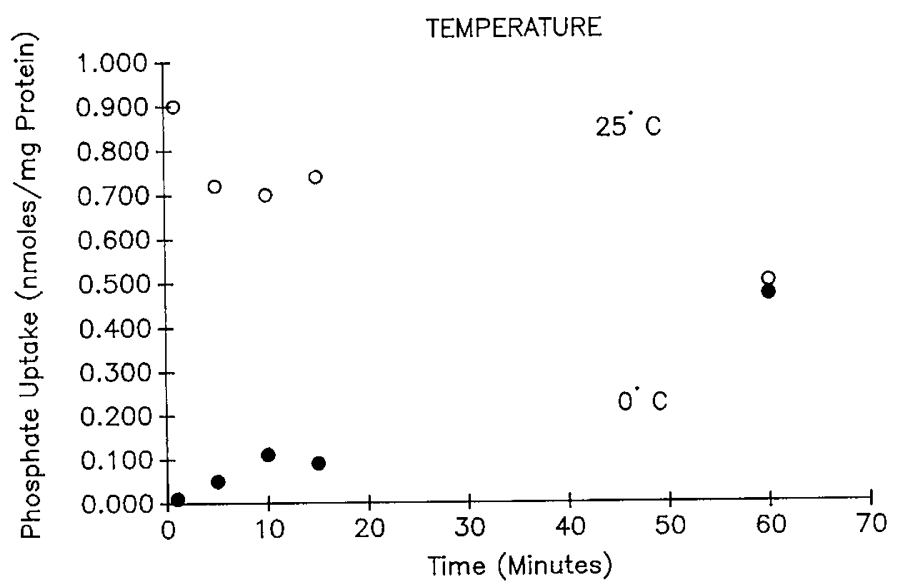

Fig. 1. Effect of temperature on phosphate uptake. Intestinal endoplasmic reticulum vesicles from adolescent rats were studied in a similar manner to ATP drive calcium conditions except that the experiments were run at $25^{\circ} \mathrm{C}$ (open circles) and $0^{\circ} \mathrm{C}$ (closed circles). Values represent mean $\pm \mathrm{SE}$ of three different experiments. SE were small and therefore not depicted. Each experiment was run in triplicate. Similar results were also obtained in suckling rats. scintillant. Radioactivity remaining in the filters after pipetting incubation medium into the radioactive substrate in the absence of vesicles was used as background and was considered in the calculations.

Purity of endoplasmic reticulum vesicles. The specific activities of enzyme markers in intestinal endoplasmic reticulum membrane vesicles and crude homogenate of epithelial cells from rats at all age groups, showed that NADPH-cytochrome-C-reductase activity was enriched 4.6 times whereas $\mathrm{Na}^{+}-\mathrm{K}^{+}$-ATPase, leucine aminopeptidase, cytochrome-C-oxidase, and galactosyl-transferase activities, markers for basolateral, brush border, mitochondrial, and Golgi membranes were impoverished (8). Electronmicroscopic examination of the endoplasmic reticulum vesicles showed sealed vesicles without contamination with either subcellular organelles.

Phosphate uptake versus binding. To determine whether phosphate uptake represented binding to the outside of the vesicles, the effect of temperature on phosphate uptake was determined by comparing uptake at 25 and $0^{\circ} \mathrm{C}$. As seen in Figure 1, uptake at $0^{\circ} \mathrm{C}$ was minimal compared to values at $25^{\circ} \mathrm{C}$, suggesting that phosphate uptake represented an energy-dependent process rather than binding.

ATP-driven phosphate uptake with time. Figure 2 depicts ATP driven phosphate uptake. In the presence of ATP, phosphate uptake was stimulated several folds compared to no ATP conditions. Peak uptake values occurred at $30 \mathrm{~s}$ in suckling rats whereas in adult rats it occurred at $1 \mathrm{~min}$. The maximal uptake in suckling rats was 10 -fold greater than corresponding values in adolescent rats. Phosphate uptake in the absence of ATP was considerably lower than corresponding values in the presence of ATP. However, uptake values in the absence of ATP were higher in suckling rats compared to corresponding values in adolescent rats.

Effect of p-chloromercuribenzoate on phosphate uptake. The effect of $100 \mu \mathrm{M} p$-chloromercuribenzoate on phosphate uptake by endoplasmic reticulum vesicles of suckling and adolescent rats was determined with time. At all time points studied $(30 \mathrm{~s}$

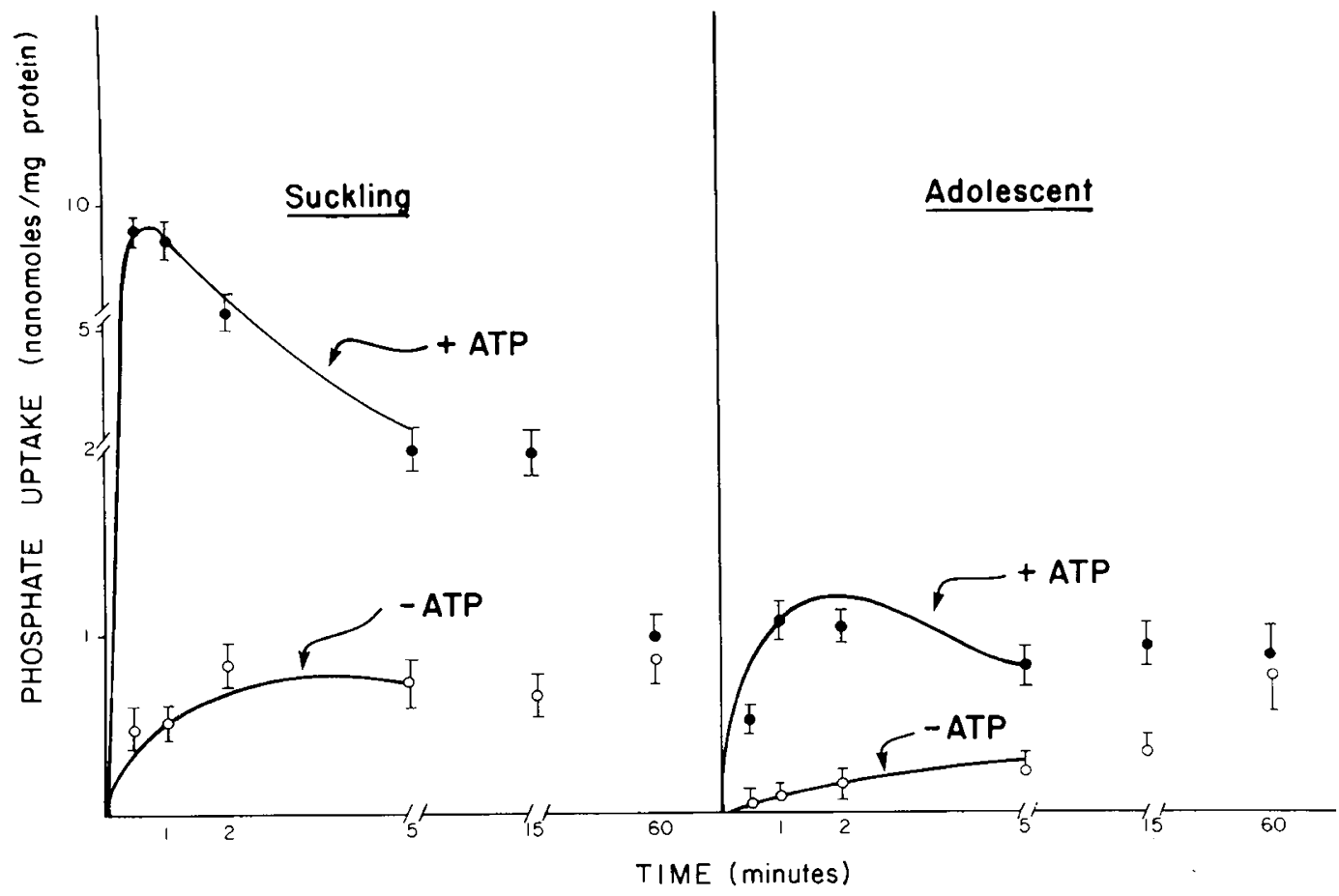

Fig. 2. ATP-driven phosphate uptake. Intestinal endoplasmic reticulum vesicles from suckling and adolescent rats were incubated in a media containing $120 \mathrm{mM} \mathrm{KCl}, 5 \mathrm{mM} \mathrm{MgCl}_{2}$, and $10 \mathrm{mM}$ Hepes-Tris buffer $\mathrm{pH} 7.2$. Reactions were started by the addition of $20 \mu \mathrm{l}$ vesicles to $80 \mu \mathrm{l}$ of an incubation media similar in composition to preincubation media containing either $5 \mathrm{mM}$ Tris ATP or no ATP and $1 \mathrm{mM}$ phosphate ${ }^{32} \mathrm{P}$ as a tracer. Reaction was stopped at desired time intervals. Values represent mean \pm SE of three different experiments. Each experiment was run in triplicate. 
to $60 \mathrm{~min}$ ), phosphate uptake was inhibited by more than $90 \%$ in both age groups.

pH optimum of phosphate uptake. To determine the $\mathrm{pH}$ optimum for ATP-dependent phosphate uptake, endoplasmic reticulum vesicles were incubated in a media containing $120 \mathrm{mM}$ $\mathrm{KCl}, 5 \mathrm{mM} \mathrm{MgCl}$, $5 \mathrm{mM}$ ATP Tris salt, and varying amount of Tris/MES buffers to result in $\mathrm{pH}$ between 5.2-7.5. As seen in Table 1, optimum uptake was maximal at $\mathrm{pH}$ of 7.2 . Similar observations were also seen in suckling rats.

Initial rate of phosphate uptake. To be able to determine the kinetics of phosphate uptake, it was essential to investigate the linearity of uptake with time. Phosphate uptake was linear up to $45 \mathrm{~s}$ as depicted by the formula $\mathrm{Y}=0.13+0.02 \times, r^{2}=0.98$. Therefore, kinetic studies were performed at $30 \mathrm{~s}$, within the linear line of uptake.

Kinetics of phosphate uptake. The kinetics of phosphate uptake in both suckling and adolescent rats are depicted in Figure $3 \mathrm{~A}$ and $B$. Phosphate uptake was measured at phosphate concentrations of $0.5-6 \mathrm{mM}$ in the presence and absence of ATP. Kinetics of phosphate uptake were calculated from uptake values with ATP minus no ATP conditions. $K_{m}$ and $V_{\max }$ were calculated using a computerized model of Michaelis-Menten kinetics (14). As seen, $V_{\max }$ of phosphate uptake by suckling endoplasmic reticulum was 10 -fold greater than uptake in adolescent rats; $0.14 \pm 0.01$ versus $1.5 \pm 0.5(\mathrm{nmol} / \mathrm{mg}$ protein $/ 30 \mathrm{~s})(p<0.01)$. $\mathrm{K}_{\mathrm{m}}$ values in suckling rats were $0.7 \pm 0.1 \mathrm{mM}$ compared to 0.15 $\pm 0.1 \mathrm{mM}$ in adolescent rats $(p<0.05)$.

\section{DISCUSSION}

Our study provides for the first time, evidence to suggest that intracellular organelles, specifically the endoplasmic reticulum of the enterocyte, possess a specialized system for phosphate uptake within the cell during early development.

Previous studies in our laboratory have shown that the endoplasmic reticulum preparation used in our studies was enriched in all age groups. NADPH cytochrome-C-reductase was enriched 4.6 times at all age groups, whereas marker enzymes for brush borders, basolateral membranes, mitochondria, and Golgi were impoverished. Phosphate uptake by the intestinal microsomes represented transport into the vesicular space rather than binding. This was evident by the temperature dependence study. Temperature dependence is a general property of carrier-mediated transport systems (15). In our studies, phosphate uptake

Table 1. pH optimum of phosphate uptake by intesinal endoplasmic reticulum*

\begin{tabular}{cc}
\hline $\mathrm{pH}$ & $\begin{array}{c}\text { Phosphate uptake } \\
(\mathrm{nmol} / \mathrm{mg} \text { protein/1 min) }\end{array}$ \\
\hline 5.2 & $0.19 \pm 0.01$ \\
5.5 & $0.34 \pm 0.1$ \\
6.0 & $0.26 \pm 0.05$ \\
6.5 & $0.23 \pm 0.02$ \\
7.2 & $1.0 \pm 0.1 \dagger$ \\
7.5 & $0.38 \pm 0.05$ \\
\hline
\end{tabular}

* Intestinal endoplasmic reticulum were incubated in a media containing $120 \mathrm{mM} \mathrm{KCl}, 5 \mathrm{mM} \mathrm{MgCl} 2,5 \mathrm{mM}$ ATP Tris salt, and varying amounts of Tris/MES buffers to results in $\mathrm{pH}$ between 5.2-7.5. For $\mathrm{pH}$ of 5.2, the molarity of Hepes/Tris was $10 \mathrm{mM}$ and MES was $25 \mathrm{mM}$; for $\mathrm{pH} 5.5 \mathrm{Hepes} /$ Tris was $10 \mathrm{mM}$ and MES was $20 \mathrm{mM}$; for $\mathrm{pH} 6.0$ Hepes/Tris was $10 \mathrm{mM}$ and MES $15 \mathrm{mM}$; for $\mathrm{pH} 6.5 \mathrm{Hepes} / \mathrm{Tris}$ was $10 \mathrm{mM}$ and MES $10 \mathrm{mM}$; for $\mathrm{pH} 7.2$ and 7.5 Hepes/Tris was $10 \mathrm{mM}$ with filtration with Tris to achieve the desire $\mathrm{pH}$. At $1 \mathrm{~min}$, uptake was terminated by adding $5 \mathrm{ml}$ of ice cold stop solution. Values are mean \pm $\mathrm{SE}$ and represents three separate experiments. Each experiment was run in triplicate.

$\dagger$ Value at 7.2 is significantly greater compared to corresponding mean values at all other $\mathrm{pH}(p<0.001)$.
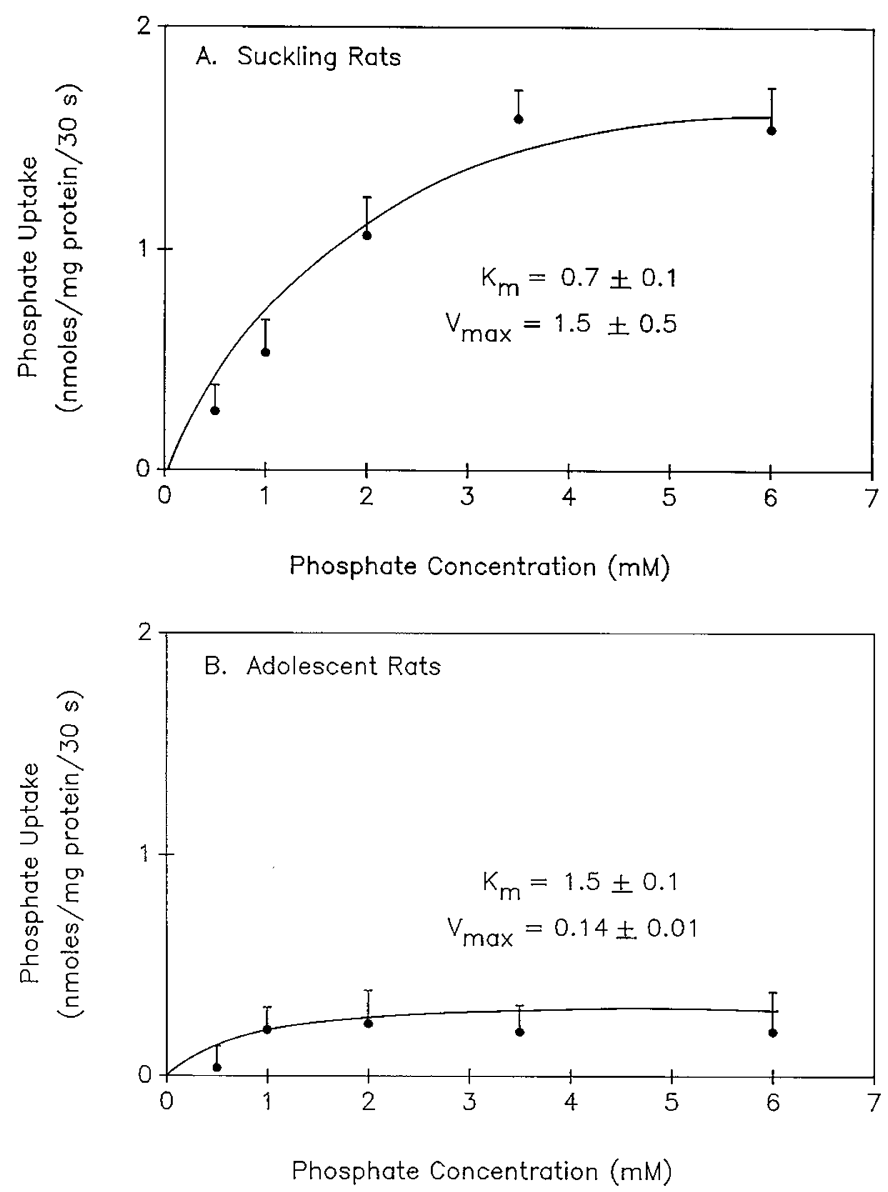

Fig. 3. $A$ and $B$, Kinetics of phosphate uptake. Intestinal endoplasmic reticulum vesicles $(20 \mu \mathrm{l})$ were added to a media containing $120 \mathrm{mM}$ $\mathrm{KCl}, 5 \mathrm{mM} \mathrm{MgCl} 2$ either $5 \mathrm{mM}$ ATP or no ATP, $10 \mathrm{mM}$ Hepes-Tris buffer $\mathrm{pH} 7.2$, different phosphate concentration $(0.5-6 \mathrm{mM})$ and tracer ${ }^{32} \mathrm{P}$. Uptake was determined at $30 \mathrm{~s}$. The data presented are values obtained with ATP minus that of uptake in the absence of ATP. Kinetic parameters $\mathrm{K}_{\mathrm{m}}$ and $\mathrm{V}_{\max }$ were obtained by computerized model of Michaelis-Menten kinetics.

at $0^{\circ} \mathrm{C}$ was less than $80 \%$ of uptake at $25^{\circ} \mathrm{C}$, which clearly demonstrates a temperature-dependent active transport process.

Phosphate uptake was ATP dependent at all age groups studied. The ATP dependency for phosphate transport at the basolateral membrane of the enterocyte was demonstrated by our laboratory (16). p-chloromercuribenzoate, a known inhibitor of phosphate uptake by the mitochondria (17), was also shown in our studies to inhibit phosphate uptake by the microsomes and suggest the involvement of a sulfahydryl group in the carrier protein. The $\mathrm{pH}$ optimum of phosphate transport was 7.2. This observation is similar to that reported for calcium transport by the intestinal microsomes (8).

Because phosphate transport for brush border membrane vesicles was significantly greater in suckling rats compared to adolescent rats (6), we postulated that intracellular transport of phosphate would also be higher. Moreover, the microsomes are known to be the site of phospholipid synthesis within the cell, which would be expected to be higher during a period of active growth. Our results confirm such a hypothesis by finding greater rates of phosphate uptake by the intestinal microsomes. This increase is secondary to increase in the number and/or activity of phosphate carriers within the microsomes. Such an increase in the number and/or activity of carrier has been reported by us recently for calcium transport by endoplasmic reticulum (8). However, the affinity of the phosphate microsomal carrier appears to be greater in adolescent rats compared to suckling rats. 
Therefore, the current studies provide evidence for a specialized phosphate carrier in the intestinal microsomes. The activity of these carriers is higher during periods of active growth and development.

\section{REFERENCES}

1. Berner WR, Kinne R, Murer H 1976 Phosphate transport into brush border membrane vesicles isolated from rat small intestine. Biochem $\mathrm{J} 160: 467$ 474

2. Danisi G, Straub R 1980 Unidirectional influx of phosphate across the mucosal membrane of rabbit small intestine. Pflugers Arch 385:117-122

3. Harrison HE, Harrison HC 1961 Intestinal transport of phosphate: action of vitamin D, calcium, and potassium. Am J Physiol 201:1007-1012

4. Harrison HE, Harrison HC 1963 Sodium, potassium and intestinal transport of glucose, 1-tyrosine, phosphate and calcium. Am J Physiol 205:107-111

5. Murer H, Hildmann B 1981 Transcellular transport of calcium and inorganic phosphate in the small intestinal epithelium. Am J Physiol 240:G409-G416

6. Borowitz S, Ghishan FK 1985 Maturation of jejunal phosphate transport by rat brush border membrane vesicles. Pediatr Res 19:1308-1313

7. Ghishan FK, Kikuchi K, Arab N 1987 Phosphate transport by basolateral membrane vesicles. Biochem J 243:641-646

8. Ghishan FK, Arab N 1988 Active calcium transport by intestinal endoplasmic reticulum during maturation. Am J Physiol 254:G74-G80

9. Rubinoff MJ, Nellans HN 1985 Active calcium sequestration by intestinal microsomes. J Biol Chem 260:7824-7828

10. Scharschmidt BF, Keefe ED, Blankenship N, and Okner R 1979 Validation of a recording spectrophotometric method for measurement of membrane associated $\mathrm{Mg}$ and $\mathrm{Mg} \mathrm{Na}^{+}-\mathrm{K}^{+}$-ATPase activity. $\mathrm{J}$ Lab Clin Med 93:790798

11. Beaufy H, Costesec AA, Feyman T, Thines-Sempoux M, Wibo M, Robie M, Berther J 1974 Analytical study of microsomes and isolated subcellular membranes from rat liver. J Cell Biol 6:88-98

12. Lowry DH, Rosenbrough N, Farr AL, Randall RJ 1951 Protein measurements with folin phenol reagent. J Biol Chem 193:265-275

13. Hopfer UK, Nelson K, Perrotto J, Isselbacher KJ 1973 Glucose transport in isolated brush border membranes from rat intestine. J Biol Chem 248:2532

14. Vaughn WK, Neal RA, Anderson AJ 1976 Computer estimation of the parameters of the sigmoid kinetic model. Comput Biol Med 6:1-5

15. DeSmedt H, Kinne R 1981 Temperature dependence of solute transport and enzyme activities in hog renal brush border membrane vesicles. Biochem Biophys Acta 648:247-253

16. Kikuchi K, Ghishan FK 1987 Phosphate transport by human basolateral membrane vesicles. Gastroenterology 93:706-711

17. Coty WA, Pedersen PL 1974 Phosphate transport in rat liver mitochondria. J Biol Chem 249:2593-2598 